\title{
Espiritualidades protestantes: A piedade na tradição luterana em torno à justificação pela fé
}

\author{
Protestant Spiritualities: \\ Piety in the Lutheran tradition around justification by faith
}

\section{Ronaldo de Paula Cavalcante*}

Princeton Theological Seminary, Princeton, Nova Jersey, EUA

\section{Resumo}

O segmento luterano deu início histórico ao Protestantismo, articulando com muito vigor uma rica relação entre piedade individual e pensamento teológico. Enfrentou com ousadia a instituição eclesiástica medieval construindo sua identidade por meio da tradução da Bíblia para a língua alemã, de comentários exegéticos dos livros bíblicos, de confissões de fé, debates, diatribes, tratados, pregações, música congregacional. Antes de tudo, desejava comunicar o Evangelho a seu povo. Construiu uma espiritualidade a partir da Bíblia, como que reagindo criticamente à cristandade e ao patrimônio da tradição, afirmando a primazia da revelação nas Escrituras, a salvação pela graça divina por meio da fé e a singularidade de Cristo em todo o processo soteriológico. Consequentemente, se envolveu em polêmicas teológicas e doutrinárias com a Igreja Católica, detentora da cultura; posicionou-se contra os protestantes radicais,

*RPC: Doutor em Teologia, e-mail: ronaldopcavalcante@yahoo.com.br 
experimentou um enrijecimento dogmático - ortodoxia protestante - na busca de equilíbrio e a subsequente renovação de sua espiritualidade em posturas pietistas moderadas ou extremas. Por um lado, contribuiu para a modernidade, por outro, reafirmou posições teológicas e espirituais dos antigos e medievais.

Palavras-chave: Piedade. Espiritualidade. Tradição luterana. Confissão de fé. Protestantismo.

\section{Abstract}

The Lutheran segment gave historical beginnings to Protestantism, articulating with great force a rich relationship between individual piety and theological thinking. He (Luther) bravely confronted the medieval ecclesiastical institution by building its identity through the translations of the Bible into the German language, exegetical commentary on biblical books, confessions of faith, debates, diatribes, treatises, preaching, congregational music. First of all, he wanted to communicate the Gospel to his people. He built a spirituality from the Bible as if reacting critically to Christianity and the heritage of tradition, affirming the primacy of revelation in the Scriptures, salvation by divine grace, through faith and the uniqueness of Christ throughout the soteriological process. Consequently, he became involved in theological and doctrinal controversies with the Catholic Church, which holds the cultures; positioned himself against radical Protestants, experienced dogmatic stiffening protestant orthodoxy - in the quest for balance and the subsequent renewal of his spirituality in moderate or extreme pietist positions. On the one hand, it contributed to modernity, on the other, it reaffirmed theological and spiritual positions of the ancient and medieval

Keywords: Piety. Spirituality. Lutheran tradition. Confession of faith. Protestantism.

\section{Introdução}

Por ser a Reforma um movimento com vínculos bem fortes em seu ambiente histórico e cultural, está necessariamente atrelado a um contexto específico de finais da Idade Média. O misticismo multifacetário da baixa Idade Média, continuaria a ter um influxo no segmento protestante 
como um todo e no luterano em particular. A Reforma, como renovação fundamental da teologia e da igreja pela Graça de Deus descoberta no Evangelho, concentrou seus esforços nos quatro axiomas centrais: sola scriptura, sola gratia, sola fides, solus Christus (somente a escritura, somente a graça, somente a fé, somente Cristo).

Sobretudo, nos reformadores se destaca o papel central das escrituras como última instância de julgamento que será determinante no modus vivendi protestante, tanto nos meios acadêmico-teológicos como na ética popular individual, familiar e comunitária. Com isso, o culto doméstico luterano ou reformado se tornou prática comum, "constituído pela leitura da Bíblia e pela oração" ${ }^{1}$, criando uma base sólida para a vida em sociedade. Nesta nova cosmovisão religiosa, a soteriologia esteve no centro como eixo, ao redor do qual gravitavam as demais doutrinas. Assim, a salvação é realizada por Cristo e alcança o pecador mediante a fé, que é obra do Espirito Santo - tudo, pois, é graça divina! O pecador perdoado continua sendo pecador na vida terrena, mas a justiça de Cristo - que lhe é atribuída (imputada) - já é o início de uma vida nova; um chamado à santificação. A salvação está no início e não no final da vida ética. A salvação é a libertação que torna o homem disponível para Deus e para o próximo. A obediência aos mandamentos do Senhor é apenas expressão de gratidão que deve perdurar toda a existência do fiel.

Muito embora, se possa reconhecer um reducionismo religioso a partir da Reforma, há que se aceitar que o movimento protestante legou ao mundo ocidental uma nova maneira de ser igreja, uma nova alternativa de cristianismo. O protestantismo se oferece não só no campo da teologia soteriológica (Justificação pela fé somente) ou eclesiológica (modelo kerigmático) mas também no campo da espiritualidade, postura que significaria em seu momento, transformações importantes para a economia, trabalho, ciência etc.

Diante disso, há que se perguntar; o que, de fato compõe a alma protestante, uma vez que todo um patrimônio tradicional de espiritualidade foi drasticamente reduzido? Sendo assim, e crendo na hipótese de que houve uma substituição de patrimônio espiritual, é que buscamos a

1 Valdo Vinay. 'Protestantes e Anglicanos'. In Tullo Goffi e Bruno Secondin (Orgs.) Problemas e perspectivas de espiritualidade. São Paulo: Loyola, 1992, p. 107. 
"Mística de Cristo", tão preciosa aos reformadores do século XVI e que foi se formando a partir de seus símbolos de fé e autores espirituais, nos vários países impactados pela Reforma.

\section{Espiritualidade luterana confessional}

O sola scriptura de Lutero, em seu caráter de objetividade, parece ser, à primeira vista, uma rejeição radical a qualquer tipo de mística cristã para a comunhão imediata com o Sagrado ${ }^{2}$. Não havendo, pois, possibilidade alguma de experiência de fé subjetiva, uma vez que a fé é confiança no Deus que se revelou na história registrada na Bíblia; como se todo o mistério divino já estivesse sido descortinado e exposto nas páginas das escrituras sagradas, bastando apenas o acesso correto a elas, sempre a partir da fé. O Crede, ut intelligas (Creia, para que possas entender) de Agostinho e o Fides quaerens intellectum (Fé que busca a compreensão) de Anselmo, são, para ele, pedras inamovíveis.

Mesmo antes de 1517, Lutero imprimiu esse modus operandi em seu pensamento teológico, base para a sua piedade. Kaufmann esclarece que "O desenvolvimento da teologia de Lutero se efetuou, de início e sobretudo, na forma de interpretações da Escritura, que empreendia ex officio (dever de função) na qualidade de pregador e professor"3. Lutero se utilizou do que havia de melhor em termos instrumentais filológicos para o entendimento correto da Bíblia. Eruditos humanistas como Johann Reuchlin, Lefèvre d'Étaples, Erasmo de Roterdã, Lorenzo Valla, John Colet e vários outros, forneceram a Lutero o indispensável para sua tarefa hermenêutica, já sinalizando um ambiente de labor científico na teologia, que viria a ser lugar comum na tradição exegética protestante alemã.

2 Em 1520, comentando sobre a obra Hierarquia eclesiástica do Pseudo-Dionísio, Areopagita, em crítica ao sacramento da Ordem, Lutero registra: "Quanto à Teologia Mística, à qual alguns dos mais ignorantes pseudoteólogos concedem tanta importância, também é muito perniciosa, pois é mais platonizante que cristianizante”. Martinho Lutero. ‘ Do cativeiro babilônico da igreja'. In Obras selecionadas, v. 2. São Leopoldo/ Porto Alegre: Sinodal/Concórdia, 1989, p. 412.

3 Thomas Kaufmann. Martín Lutero: Vida, mundo, palabra. Madrid: Trotta, 2017, p. 38. 
No entanto, a partir de uma leitura mais refinada, tanto de Lutero quanto da tradição luterana, constata-se a presença da mística no movimento reformista. De fato, no reformador de Wittenberg, pode-se perceber, não apenas fortes sinais místicos, mas igualmente, uma reformulação da mística como vivência da paixão do Senhor, distanciada do modelo medieval que se apoiava sobre a imitatio Christi (Imitação de Cristo) e o seguimento de sua paixão que ele supera ou transforma ${ }^{4}$. O teólogo luterano Paul Tillich, não obstante, em um primeiro momento, colocar sob suspeição "o misticismo católico" na interpretação que faz de Lutero ${ }^{5}$, dedica ao tema extensas páginas em sua teologia sistemática ${ }^{6}$, nomeando como "Presença Espiritual" e vinculando-o ao "princípio protestante”. A afirmação de um locus místico na Reforma, por meio da doutrina da justificação pela fé, por parte de Paul Tillich é, de maneira original e criativa, constatada por $C$. Thompson quando analisa o Cântico espiritual de São João da Cruz. O mesmo avalia, por outro lado, negativamente a posição de Barth, como que concluindo que no luteranismo sim — há um locus, no calvinismo não! Essa certeza emana, por exemplo, de quando Lutero escreve em tons claramente místicos, no seu Tratado sobre a liberdade cristã:

[...] A terceira incomparável graça da fé é esta: a alma é copulada com Cristo como a noiva com o noivo, sacramento pelo qual (como ensina o apóstolo) Cristo e alma são feitos uma só carne. Sendo eles uma só carne, é consumado entre eles o verdadeiro matrimônio, sim o mais perfeito de todos... Daí se segue que tudo se lhes torna comum tanto as coisas boas quanto as más, de modo que a alma fiel pode apropriar e gloria-se de tudo que Cristo possui como sendo seu, e de tudo que tem a alma, Cristo se apropria como se fosse seu... Pois se Ele é o noivo, tem, simultaneamente, aceitar o que é da noiva e compartilhar com a noiva o que é seu... Assim a alma do crente se torna livre de todos os pecados pelas arras de sua fé em Cristo, seu noivo a segura contra a morte e protegida do inferno, presenteada com

4 Adolfo G. Montes. Reforma luterana y tradicón católica. Salamanca: UPS, 1987, p. 169.

5 Paul Tillich. História do pensamento cristão. São Paulo ASTE, S/d. “... Lutero respondia dizendo que nenhum sacramento é eficaz por si mesmo sem a plena participação de quem o recebe, isto é, sem ouvir a Palavra relacionada com o sacramento, e sem a fé que 0 aceita. Os sacramentos enquanto tal nada valem. $E$ assim Lutero destrói o lado mágico do pensamento sacramental". (p. 217).

6 Paul Tillich. Teologia sistemática. São Leopoldo/São Paulo: Sinodal/Paulinas, 1987, p. 569-571.

7 Colin Thompson. El poeta y el místico: Un estudio sobre el “Cántico espiritual de San Juan de la Cruz. Madrid: Torre de la Botica Swan, 1963, p. 219. 
eterna justiça, vida, salvação de seu noivo Cristo... Segundo Cantares: “O meu amado é meu e eu sou dele" $[2,16][\ldots]^{8}$.

$\mathrm{Na}$ mesma linha de teólogos antigos e medievais que comentaram o Cântico dos Cânticos, desde Orígenes e Gregório de Nissa até San Juan de la Cruz, passando por San Bernardo de Clairvaux e Fray Luis de León, Lutero reafirma a experiência mística da alma humana quando se enamora e se entrega a Cristo - unio mystica (união mística) - consumando o "verdadeiro matrimônio" espiritual.

H. Oberman, um dos principais especialistas em Lutero ${ }^{9}$, declara que nele havia uma mística para a vida sob a influência de J. Staupitz e J. Tauler. Deste, publicou a Theologia Deutsch em 1516 e 1518. Se utiliza de Tauler para compreender a tensão existencial da alma - o simul iustus et peccator $^{10}$ (simultaneamente justo e pecador) - por um lado a alma soluça por sua condição de pecado e por outra, está em êxtase pela união com Deus. Ela experimenta suspiros e arrebatamentos ${ }^{11}$. Por isso mesmo, em Lutero seria um simplismo teológico afirmar que o indivíduo justificado é justo; para ele o justificado é justo e pecador juntamente, concomitantemente, simul! O. H. Pesch, interpretando Lutero sobre o simul, pontua que "a justiça que se dá, juntamente com o pecado consiste em que Deus "não imputa" ao pecador seu pecado e o "estima" como justo, continuando, portanto,

8 LUTERO, M. Tratado sobre a liberdade cristã. In: Obras selecionadas, v. 2. São Leopoldo/Porto Alegre: Sinodal/ Concórdia, 1989. p. 442-443. Este tratado está também em edição separada: Martim Lutero. Da liberdade cristã. São Leopoldo: Sinodal, 1998. Obra seminal da teologia luterana e protestante, integrante dos escritos de 1520 na WA 7,49-73 - Tractatus de libertate christiana. Em Alemão: Freiheit eines Christenmenschen. Em Português conhecida simplesmente como "Da liberdade cristã", onde logo no início se encontra seu famoso paradoxo: “0 cristão é um senhor libérrimo sobre tudo, a ninguém sujeito. 0 Cristão é um servo oficiosíssimo de tudo, a todos sujeito", p. 437.

9 Sobre Lutero e seu pensamento, recomendo: DREHER, M. N. De Luder a Lutero: uma biografia. São Leopoldo: Sinodal, 2014; FEBVRE, L. Martín Lutero: un destino. México: FCE, 2004; ROPER, L. Martin Luther: renegade and prophet. London: Penguin Randon House, 2017; KAUFMANN, T. Martín Lutero - vida, mundo, palavra. Madrid: Trotta, 2017; EBELING, G. 0 pensamento de Lutero. São Leopoldo: Sinodal, 1988; OBERMAN, H. Lutero: Un hombre entre Dios y el diablo. Madrid: Alianza Editorial, 1992.

10 Axioma mencionado literalmente em suas preleções sobre a Carta de São Paulo aos Gálatas, que foram proferidas entre julho e dezembro de 1531 na Universidade de Wittenberg. "Assim, o cristão é, ao mesmo tempo, justo e pecador, santo e profano, inimigo e filho de Deus". Martinho Lutero. Interpretação do Novo Testamento, Gálatas - Tito. In: Obras selecionadas, v. 10. São Leopoldo/Porto Alegre/Canoas: Sinodal/ Concórdia/Ulbra, 2008, p. 227.

11 OBERMAN, H. Lutero: Un hombre entre Dios y el diablo. Madrid: Alianza Editorial, 1992, p. 224. 
na verdade - "in re" - pecador ${ }^{12}$. Mais de uma vez, Lutero reconheceu a Staupitz como mentor espiritual, "O senhor Jesus me direcionou e fortaleceu repetidas vezes de forma maravilhosa por meio de Staupitz"13. Lutero tentou elaborar uma simbiose entre teologia agostiniana de Staupitz, e a via moderna de G. Biel e G. de Ockham, mesclando nominalismo com a mística especulativa de Tauler e criando um novo tipo de piedade, com forte acento pessoal do indivíduo sozinho, coram Deo! (perante Deus!).

Ademais, no contexto da distinção entre a lei e o Evangelho — opus meum e opus Dei, opera theologica e opera moralia e naturalia, (obra própria e obra de Deus, obra teológica e obra moral e natural), é que Lutero explicará teologicamente a natureza desse intercâmbio sublime entre Cristo e a alma como sendo em conformitas cum Christo (conformidade com Cristo) outorgada ao pecador como opus alienum (obra alheia) contra a pretensão tentada de pelagianismo, segundo se expressa, na consideração teológica da Imitatio Christi como opus propium (obra própria), Lutero chega a explicar o sentido teológico último do intercâmbio entre Cristo e a alma a partir da unidade que graças à sacramentalidade da paixão do Senhor se estabelece entre Cristo e o pecador ${ }^{14}$. A profundidade do intercâmbio místico está descrita como communio idiomatum (comunhão de atributos) e diz respeito ao processo kenótico, no qual acontece a permuta da humanidade de Cristo com a humanidade do pecador.

Dessa forma, Lutero redescobre o caráter sacramental da humanidade de Cristo, precisamente em virtude da sua análise e vivência da significação teológica da kénose (esvaziamento) do Salvador, fundamento da mística da conformitas cum Christo, sobre a qual Lutero sustenta sua experiência da misericórdia divina na fórmula nupcial do intercâmbio, conforme vimos acima. Lutero, pois, partindo de São Paulo, aperfeiçoa, por assim dizer, toda a tradição mística medieval do seguimento e imitação de Cristo e desde tal piedade místico-ascética da compassio et imitatio

12 PESCH, O. H. `La gracia como justificación y santificación del hombre’. In: Misterium Salutis - Manual de teologia como historia de la salvación IV/2 - La Iglesia. Madrid: Cristiandad, 1984, p. 845. Pesch aprofunda o entendimento do axioma luterano: o justificado é durante toda sua vida "parcialmente justo e parcialmente pecador" ("partim iustus, partim peccator") [...] "pecador na realidade e justo na esperança" ("peccator in re, iustus in spe").

13 Ibid., op. cit, p. 218. [Citação de WA 1, 525, 4-6 (1518).

14 Ver: Adolfo G. Montes, op cit., p. 176-179. Onde cita WA 51, 83, 18; WA 36, 229,3; WA 40, 412, 4. 
Jesu Christi (compaixão e imitação de Cristo), concentrada no prototipismo do Senhor, passa à sua mística do feliz intercâmbio nupcial. Isso põe de relevo que Lutero culminou o processo de assunção da tradição místico-medieval, quando decide formular sua doutrina da justificação a partir do conceito de iustitia passiva (justiça passiva), "no sentido de que deixemos unicamente Deus atuar em nós e que nada de próprio obremos com todas as nossas forças"15, que crê descobrir em Santo Agostinho lendo Romanos 1,17 como arranque e o estar-em Cristo como condição única.

Entretanto e obrigatoriamente, apesar de todo esse background teológico e filosófico ${ }^{16}$ implícito no pensamento de Lutero, construindo seu rigoroso preparo acadêmico, suas incomuns descobertas teriam que se adaptar aos tempos de embates e polêmicas com o catolicismo e com os radicais do movimento protestante. Diante disso, e para além de tais questões externas, era imperiosa a definição confessional do ramo protestante por uma questão de identidade, de sobrevivência e para a sua própria segurança doutrinária. Nesse intuito, em 1529 foi publicado o Catecismo Menor de Lutero ${ }^{17}$. Esse pequeno livro, chamado pelo autor de Enchiridion, foi mais o resultado de um gradual desenvolvimento do que o produto de um súbito impulso. Desde que Lutero veio a Wittenberg como professor e pastor, ele pregou regularmente sobre os fundamentos da fé cristã. Em sermões, ele apresentou aos ouvintes, tanto jovens como velhos, uma explanação clara e simples da lei divina do Credo (ou Evangelho), do Pai nosso, Batismo e Santa Ceia. Por essa razão o seu Catecismo foi o fruto amadurecido de longos e cuidadosos estudos na área da educação cristã popular ${ }^{18}$. Na forma de perguntas e respostas, procurava remediar a ignorância das Escrituras, tanto dos pastores quanto dos leigos. Por isso, foi utilizado também pelos professores nas escolas e pelos pais no lar. As crianças luteranas o estudaram desde a escola primária,

15 BAYER, O. Viver pela fé: justificação e santificação. São Leopoldo: Sinodal, 1997. p. 22.

16 EBELING, G. 0 pensamento de Lutero. São Leopoldo: Sinodal, 1988. Afirma que "Para Lutero, a formação occamista teve continuidade também nos estudos teológicos". (p. 28).

170 texto completo pode ser encontrado no "Livro de Concórdia" de 1580. Em Português temos a edição: Os Catecismos. Tradução de Arnaldo Schüller. Porto Alegre/São Leopoldo: Concórdia/Sinodal, 1983, com excelente aparato crítico nas notas de rodapé.

18 MUELLER, J. T.; REHFELDT, M. L. As confissões luteranas, história e atualidade. Porto Alegre: Concórdia, 1980. p. 17. 
na Escola Dominical e na classe de confirmandos ${ }^{19}$. A espiritualidade do Catecismo menor é destacada na exposição que Lutero faz sobre os Dez Mandamentos, o Credo, o Pai nosso e, sobretudo, dos sacramentos do Batismo e $\mathrm{Ceia}^{20}$ e também os apêndices que compreendem as orações para antes das refeições, para manhã e noite. São oportunos exemplos para a comunhão cristã com Deus por meio de súplica e ação de graças e uma tábua de deveres que deve ser diligentemente estudada.

O terceiro artigo do Credo está dedicado à santificação. Após a profissão de Fé: "Creio no Espirito Santo, uma santa igreja cristã, a congregação dos santos, a remissão dos pecados, a ressurreição da carne e a vida eterna. Amém"; Lutero, em resposta diz que "[...] o Espirito Santo me chamou e pelo evangelho; iluminou com seus dons, santificou e conservou na verdadeira fé" 21 . O Ponto central, no entanto, é quando expõe acerca do relacionamento com Cristo. Ao sacrifício de Cristo "[...] com seu santo e precioso sangue, sua inocente paixão e morte", corresponde, segundo Lutero, o pertencer de maneira viva e submissa a Ele, e sirva em eterna justiça, inocência e bem-aventurança [...]"22. Esta ênfase num relacionamento íntimo tanto com o Espírito Santo, quanto com Jesus Cristo, caracterizará toda a espiritualidade luterana, no contexto da doutrina do Sacerdócio universal de todos os santos.

Em 1530, foi publicada a Confessio Augustana ${ }^{23}$, considerado o principal documento confessional do luteranismo. Junto com sua Apologia, que é sua explanação mais longa, foi adotada como um testemunho contra os abusos que se acrescentaram no ensino e na praxis da igreja antes da Reforma, e contra os erros dos reformadores radicais. Ela foi escrita por Felipe Melanchthon, o mais famoso professor, colega e discípulo de

19 Ibid., op. cit., p. 18.

20 Conf. p. 366-376. Esta numeração de páginas segue 0 Livro de Concórdia. [Edição comemorativa dos seus 400 anos]. Porto Alegre: Concórdia, 1980, por ser uma separata deste.

21 Ibid., op. cit., p. 371.

22 Ibid., loc cit.

23 O texto completo da Confissão de Augsburgo em Português pode ser encontrado em 0 livro de concórdia. [Edição comemorativa dos seus 450 anos]. Porto Alegre: Concórdia, 1980 e ainda A confissão de Augsburgo Das Augsburger Bekenntnis 1530-1980. [Edição bilíngue]. São Leopoldo: Sinodal, 1980. Sobre os principais documentos confessionais protestantes em geral, ver meu artigo: Reforma protestante, 500 anos - Ensaio de Crítica Histórica. Revista Pistis \& Praxis Teologia Pastoral, v. 9, n. 2, 2017. 
Lutero em Wittenberg. A Confissão está baseada em artigos de fé redigidos por teólogos luteranos, e em sua maior parte, por Lutero. Além de uma teologia sacramental, eclesiológica, soteriológica, a Confissão sublinha uma espiritualidade ligada à vida prática, ou seja, para o homem comum no seu cotidiano. No artigo 6 - Da nova obediência, lemos:

Ensina-se que essa fé deve produzir bons frutos e boas obras e que, por amor de Deus, se deve praticar toda sorte de boas obras por Ele ordenadas, não se devendo, porém, confiar nessas obras, como se por elas merecesse graça diante de Deus. Pois é pela fé em Cristo que recebemos perdão dos pecados e justiça, como diz o próprio Cristo: "depois de haverdes feito isso, deveis dizer: somos servos inúteis". Assim também ensinam os pais. Pois Ambrósio diz: "Assim está estabelecido por Deus que aquele que crê em Cristo é salvo, e tem remissão dos pecados não por obras, mas pela fé somente, sem mérito ${ }^{24}$.

Percebe-se que as boas obras compõem o núcleo da espiritualidade luterana, embora devam ser colocadas no seu devido lugar. Os confessores de Augsburgo revelam com clareza em que sentido podemos e precisamos fazer o bem. Não se pode alegar, portanto, que os luteranos não queiram e não saibam ensinar boas obras. Apontam também o perigo de olharmos para o bem que fazemos, em vez de concentrar somente em Cristo a esperança da vida eterna. N. Beck comenta: "Portanto façamos todo empenho para manter esta dupla verdade: Deus quer que façamos o bem, mas não quer que deixemos de recorrer a Cristo pela fé, como nossa única justiça que reconhece e aceita" ${ }^{25}$. Nota-se um esforço de equilíbrio entre a graça de Deus e a responsabilidade humana.

O artigo 12 - Do arrependimento, estabelece:

Do arrependimento se ensina que os que pecaram depois do batismo, recebem perdão dos pecados a qualquer tempo em que cheguem ao arrependimento, não lhes devendo a igreja negar absolvição. Agora,

24 Em Alemão o título é: Von Neuen Gehorsam. A citação de Ambrósio, na verdade, é um comentário latino a Paulo, datado do século IV, denominado "Ambrosiaster", que na Idade Média foi atribuído ao bispo de Milão.

25 Nestor Beck em comentário ao artigo 6 da Confissão da esperança: Exposição histórica e doutrinária da Confissão de Augsburgo. Porto Alegre: Concórdia, 1980. p. 52. 
arrependimento verdadeiro, autêntico, propriamente outra cousa não é que sentir contrição e apesar ou terror por causa do pecado e, todavia, crer ao mesmo tempo no evangelho e na absolvição, isto é, crer que o pecado foi perdoado e que por Jesus Cristo foi obtida a graça, fé essa que volta a consolar e serenar o coração. Deve seguir-se a melhora de vida e abandono do pecado; pois essas devem ser os frutos do arrependimento, como diz João o Batista em Mt 3: "Produzi, pois fruto de arrependimento [... $]^{26}$.

L. Heinmann, pontua que "Este verdadeiro arrependimento em contrição e fé é obra do Espírito Santo que atua através da pregação clara da lei e evangelho ${ }^{27}$. O vínculo necessário do arrependimento com a pregação da Palavra será no luteranismo, na ação do Espírito santo, cláusula pétrea e princípio de fé.

Em 1580, foi publicado o Livro de Concórdia ${ }^{28}$. É a única confissão luterana escrita e adotada após a morte de Lutero. Ela deve sua origem a uma série de conturbadas controvérsias dentro da Igreja Luterana, estas que duraram cerca de 30 anos. A Fórmula de Concórdia está composta por doze artigos. Ali se diz que a imputação da justificação divina é imediatamente seguida pela santificação, quando o crente vivificado em Cristo e moído pelo Espirito Santo se esforça para glorificar a Deus pela verdadeira santidade de vida. $\mathrm{O}$ artigo 6 destaca a necessidade da lei divina para ter acesso à vontade de Deus como guia de comportamento para uma vida piedosa. $\mathrm{O}$ artigo 8 ensina a verdadeira união entre a duas naturezas de Cristo e a comunicação de seus atributos, como base para a presença real. A união pessoal das duas naturezas em Cristo é tão íntima e a comunicação dos atributos tão real que os atributos de ambos são atribuídos ao Cristo, que é uma só pessoa. Por isso, ambas as naturezas cooperam, com seus atributos, na obra redentora, e a natureza humana de Cristo, pela união pessoal, recebeu a majestade e glórias divinas. No artigo 11 se ensina a confortante doutrina da eterna eleição da graça de Deus para a salvação. Lutero expressou esta verdade

26 Em Alemão o título é: Vom Der Bube. Confissão da esperança, p. 85.

27 Leopoldo Heimann em comentário ao artigo 12 da Confissão da esperança... p. 88.

280 livro de concórdia. [Edição comemorativa dos seus 400 anos]. Porto Alegre: Concórdia, 1980, contendo os principais documentos confessionais e apologéticos da fé cristã: Os Credos: Apostólico, Niceno, Atanasiano; a Confissão de Augsburgo, a Apologia da Confissão de Augsburgo; os Catecismos: Menor e Maior; os Artigos de Smalkalde; o Tratado sobre o Poder do Papa e a Fórmula de Concórdia. 
dizendo que os cristãos devem buscar a certeza da sua eleição e salvação nas "feridas abertas de Cristo". Por isso, eles devem confiar em Cristo e crer que nEle foram redimidos e eleitos.

A Fórmula de Concórdia termina com a seguinte oração: "Que o Deus todo poderoso, o Pai de nosso Senhor Jesus Cristo nos conceda a graça de seu Espirito Santo, para que todos sejamos unidos nEle e constantemente permaneçamos nessa unidade cristã, que lhe é agradável. Amém". A tentativa de concórdia era clara nesse momento, os vários grupos protestantes, ademais do catolicismo, passados pouco mais de meio século desde a polêmica das indulgências, gritava pela unidade cristã como que antevendo a Paz de Westfália (1648), pondo termo às Guerras de Religião e à Guerra dos Trinta anos na Europa.

\section{A espiritualidade Luterana Pietista}

Os primeiros 60 anos da tradição luterana, em geral, foram a incubadora na qual se forjou uma espiritualidade tendo por base a Bíblia, e nela, a theologia crucis $^{29}$ (teologia da cruz) em conjunção com a doutrina da justificação pela fé3 ${ }^{30}$, ambas diretamente extraídas das obras de Lutero, em sua interpretação das Escrituras. No caso da doutrina da justificação pela fé, O. Bayer, com base nas palavras de Lutero, interpreta o axioma articulus stantis et cadentis ecclesiae (artigo pelo qual a igreja está de pé ou cai) com

29 Em estreita relação com o tema do Deus absconditus debatido em Heildelberg (1518). Ver a respeito: EBELING, G. 0 pensamento de Lutero. São Leopoldo: Sinodal, 1988. p. 180ss; von LOEWENICH, W. A teologia da cruz de Lutero. São Leopoldo: Sinodal, 1988. p. 21-44 e 146-168; THIEMANN, R. F. 'A teologia da cruz de Lutero: Subsídio para uma teologia das religiões'. In: HELMER, C. (Ed.). Lutero: Um teólogo para os tempos modernos. São Leopoldo: Sinodal, 2013. p. 255-273.

30 Considerado o ponto central da teologia de Lutero - Articulus stantis et cadentis ecclesiae. Lutero falou e ensinou inúmeras vezes sobre a justificação; ver, por exemplo: ‘Debate Acerca da Justificação' (1535). In: Martinho Lutero: Obras selecionadas, v. 3. São Leopoldo/Porto Alegre: Sinodal/Concórdia, 1992. p. 201239; 'Prefácio à epistola de S. Paulo aos Romanos' (1546). In: Martinho Lutero: Obras selecionadas, v. 8. São Leopoldo/ Porto Alegre: Sinodal/Concórdia, 2003, p. 129-141; “Epistola do bem-aventurado Apóstolo Paulo aos Romanos' (1515-1516). In: Martinho Lutero: Obras selecionadas, v. 8. São Leopoldo/Porto Alegre: Sinodal/Concórdia, 2003. p. 254-260, onde afirma: "Por isso, o significado da sentença parece ser o de que a justiça de Deus provém exclusivamente da fé, de tal forma que, à medida que ela progride, a justiça não fica à vista, mas cresce sempre em direção a uma fé mais clara..." (p. 260).

Rev. Pistis Prax., Teol. Pastor., Curitiba, v. 10, n. 3, 657-681, set./dez. 2018 
maior "amplitude de significado da justificação em termos ontológicos e da teologia da criação" ${ }^{1}$. Isso significa, como pensa A. G. montes, "como um critério ou corretivo para toda prática, estrutura e teologia da Igreja [...] o coração do Evangelho"32. Por sua vez, A. Schweitzer ${ }^{33}$, por exemplo, entendia que a doutrina da justificação pela fé, interpretada pelos teólogos tradicionais, em termos forenses, separada da doutrina da redenção e essa por sua vez fincada na doutrina mística do estar-em Cristo, foi um equívoco. Algo como um reducionismo fideísta. Por isso, contra essa ideia redutora da justificação pela fé, há que se considerar tal doutrina como sendo um produto da redenção, e a ela submissa. Textualmente ele diz: "A doutrina da justificação pela fé, é, pois, uma cratera auxiliar, que foi formada dentro da cratera principal - a doutrina mística da redenção por meio do estar-em Cristo" 34 . Para ele, pois, a interpretação de Lutero da teologia paulina seria unilateral, condicionada dogmaticamente, entre outras, por seu contexto beligerante com o catolicismo. Lutero teria concebido a justificação não mais como habitus no sentido medieval de gratia inherens (graça inerente), mas como imputação da justiça de Cristo nos pecadores, portanto uma ação extrínseca - extra nos (fora de nós). Não obstante, como observa Pesch, "Nem Lutero nem nenhum outro dos grandes reformadores jamais duvidou de que a ação divina justificante renova o homem, por conseguinte, tem "efeito" e, nesse sentido, é efetiva" ${ }^{\text {. S }}$ Seguindo essa linha de raciocínio, a justificação deveria ser interpretada dentro de uma tradição mística maior. Na sequência histórica do luteranismo, entre a justificação forense de uma declaração de justiça

31 BAYER, O. A teologia de Martim Lutero. São Leopoldo: Sinodal, 2007. p. 71. Ver ainda p. 29, 40-41, 54, 6972. Cita Lutero: "Sem o artigo da justificação, o mundo nada é além de morte e trevas" (WA 39 I,205,5).

32 MONTES, A. G. Justificados en JesuCristo: La justificación en el diálogo ecuménico actual. Salamanca: UPS. p. 48.

33 SCHWEITZER, A. The mysticism of Paul the apostle. Baltimore/London: The John Hopkins University Press, 1998. Ele diz: [os eruditos] "Ao considerar a doutrina da justificação pela fé como um ponto de partida, o entendimento da cosmovisão paulina tornou-se impossível” (p. 220). Schweitzer, nesse ponto, segue Adolf Deissmann. Paul: a study in social and religious history. New York: Harper, 1957, p. 155 e 167-178, para quem a Justificação em Paulo deve ser lida sempre dentro da doutrina da Redenção. Uma Excelente descrição e avaliação do tema da mística de Cristo em Paulo, citando Deissmann, Schweitzer, Bousset e outros, pode ser vista em James Dunn. A teologia do apóstolo Paulo. São Paulo: Paulus, 2003, p. 454- 475.

34 Ibid., op cit., p. 225. Penetrantes reflexões acerca do tema da Justificação e do estar-em Cristo, podem ser vistas em Ernst Käsemann. Perspectivas paulinas. São Paulo: Teológica, 2003. p. 116-129; 161-162.

35 Otto H. Pesch, op cit., p. 805.

Rev. Pistis Prax., Teol. Pastor., Curitiba, v. 10, n. 3, 657-681, set./dez. 2018 
ou efetiva de tornar justo ao homem, em geral se optou por aquela, uma vez que o pecado exclui a possibilidade de uma justiça real, mantendo a identidade paradoxal de juízo e graça. Isso quer dizer que Lutero segue a tradição vétero-testamentária, entendendo o ato de justificar como passivo - o homem é declarado justo. Entretanto, o teólogo protestante, P. Bonnard, concorda com Pesch, diz ele:

Esta justiça "imputada" ao crente por Deus, note-se bem, é justiça real. O homem a quem Deus já não imputa os pecados por causa de Jesus Cristo, é justo... Ele é "pecador perdoado", portanto realmente justo ${ }^{36}$.

Nessa mesma linha, Vajta, teólogo reformado de Estrasburgo, ratifica a efetividade da Justificação pela fé no sentido protestante, para ele, "[...] pela palavra e pela fé a justiça de Deus opera nossa justificação por Cristo presente e operante nesta palavra e nesta fé" ${ }^{37}$. Isso indica que a dedução da declaração de justiça não ser justiça real, não faz sentido, "A alternativa entre uma justiça forense imputativa e uma justiça real e atual, está, sem sombra de dúvida, mal elaborada"38. Quando Deus disse "Haja luz, houve luz"; quando Deus declara o homem justo o homem é feito justo, ainda que simultaneamente pecador, mantendo-se o paradoxo da existência humana.

O produto final desse processo permaneceu estampado e fixado tanto na Confessio Augustana quanto na Fórmula de Concórdia, que veio a ser conhecido como ortodoxia luterana ${ }^{39}$. Período conhecido por suas características aristotélicas e, portanto, fará às vezes de uma escolástica em solo protestante. Na medida em que foi aceita pela teologia, tal filosofia escolástica alemã serviu para fortalecer a tendência intelectualista que caracterizou a ortodoxia luterana ${ }^{40}$. Do ponto de vista da teologia

\footnotetext{
36 BONNARD. 'Justo'. In: Jean-Jaques von Allmen (dir.). Vocabulário Bíblico. São Paulo ASTE, 2001. p. 302.

37 V. Vajta. 'Justificação'. In: Yves Congar (dir.). Vocabulario Ecuménico. Barcelona: HERDER,1972, p. 121.

38 Ibid., op cit,. p. 121.

39 Acerca da ortodoxia luterana, ver especialmente as reflexões de TILLICH, P. História do pensamento Cristão. São Paulo: ASTE, 1992. p. 251-256; LOHSE, B. A fé cristã através dos tempos. São Leopoldo: Sinodal 1981. p. 231-244; HÄGGLUND, B. História da Teologia. Porto Alegre: Concórdia, 1981. p. 259-279.

40 B. Hägglund, op. cit., p. 259.
} 
sistemática, a época da ortodoxia é considerada muito fértil, pelo fato de, por exemplo, ter estabelecido uma definição acerca da relação entre razão e revelação. Se Lutero teria concordado in totu (na totalidade) com a ortodoxia, é tema debatido desde aquela época.

Outrossim, Bayer ${ }^{41}$ reconhece em Lutero uma presença de um tipo de mística. Johannes Tauler, como já dito, foi sempre ressaltado por ele, todavia, com o seu conceito revolucionário de fé como vita passiva (vida passiva), Lutero tratou a mística de modo crítico. Pode-se entender, pois, porque a reação a este racionalismo na dogmática cristã luterana não se fez esperar, uma vez que na própria dogmática estava presente a doutrina da ordo salutis (ordem da salvação) e no seu último estágio a unio mystica. O desenvolvimento dos fatos mostra que foi o pietismo o primeiro a se levantar contra a ortodoxia, e que em breve seria seguido por um movimento de alcance bem mais amplo. Daniel de Pablo Maroto, especialista católico em espiritualidade, e bom conhecedor do protestantismo sintetiza a espiritualidade luterana com dez princípios fundamentais. Seleciono, a seguir, dentre esses princípios, os que estão relacionados diretamente com a mística de Cristo:

A fé em Cristo gera a salvação-justificação, porém, Lutero não podia entender que se tratasse de uma transformação interior da alma em Deus, de uma semelhança ontológica com Deus em virtude da graça, transformação que levou aos limite os místicos, senão por mera imputação extrínseca dos méritos de Cristo, por meio da qual, Deus considera o pecador como se não fosse, pois objetivamente é pecador [...] A fé e a justificação tornam o homem livre [...] livre pela fé, escravo pelo amor [...] O luteranismo é uma piedade eminentemente cristocêntrica... Cristo é o único mediador diante do Pai mediante a morte na cruz. Lutero desenvolveu, como poucos, antes e depois, uma lúcida teologia da cruz, meditação cognoscitiva da divindade, crítica permanente à Igreja [...] Admite somente dois sacramentos, a ceia e o batismo [...] a eles há que acrescentar a Palavra. São sinais externos para motivar a fé do crente [...] O luteranismo gerou um modo específico de viver o cristianismo [...] vida simples, alegre, nada burguesa [...] Ao ser uma teologia fundamentada na Escritura revelada, era

41 BAYER, O. A teologia de Martim Lutero. São Leopoldo: Sinodal, 2007. p. 31-32. Bayer nos relembra o Sermão sobre as boas obras - (WA 6, 244,3-6). "que deixamos Deus agir sozinho em nós e nós mesmos com todas as nossas forças não efetuamos nada próprio". 
bem existencial, nada abstrata, e por isso mesmo exigia uma nova moral e alegre espiritualidade $[. . .]^{42}$.

Como se sabe, Philipp Jacob Spener (1635-1705), é considerado o fundador do pietismo alemão ${ }^{43}$. Que, não obstante ter concordado em vários pontos com a ortodoxia, a criticou especialmente na sua doutrina da inspiração verbal das escrituras como impraticável nas igrejas luteranas. Em uma viagem à Suíça, estabeleceu contato com os ensinamentos de Jean Labaldie, um ex-jesuíta que insistia em que a inspiração imediata do Espírito Santo era necessária para poder entender as Escrituras ${ }^{44}$. Após seu regresso à Alemanha, serviu como pastor, primeiramente em Estrasburgo e depois em Frankfurt, onde iniciou em pequenos grupos que se reuniam em casas, as experiências de Labaldie. Igualmente em Frankfurt publicou, em 1675, o livro que se tornaria o manual do pietismo: Pia desideria ${ }^{45}$ (Desejos piedosos). Nesta obra, propôs várias recomendações para reformas destinadas a curar o estado de decadência da igreja, por exemplo, que a Bíblia fosse estudada mais intensivamente. $\mathrm{O}$ ambiente desse estudo seria o de pequenas associações para experimentar a vida piedosa, os - colegia pietatis (grupos de piedade) — onde a doutrina do sacerdócio universal seria exercitada por meio de admoestação mútua, exortação, correção, conforto, quer dizer, a atividade pastoral. Como explicou Hägglund, “Também expressou o desejo de reformar o estado da teologia: o método dialético deveria ser substituído pela leitura da Bíblia e literatura da Bíblia e literatura devocional"46. Buscava-se, pois, uma renovação interna do luteranismo, tanto de sua prática pastoral quanto da própria formação teológica, ambas deviam ser alicerçadas na Bíblia.

Spener pode demonstrar que os elementos fundamentais do pietismo já estavam presentes no pensamento de Lutero e que a ortodoxia se afastara desses elementos, em favor do conteúdo objetivo da doutrina.

42 Em História de la espiritualidade cristiana. Madrid: EDE, 1990. p. 262-265.

43 Acerca do Pietismo, ver em Português, especialmente: TILLICH, P. História do Pensamento Cristão. São Paulo: ASTE, s/d. p. 257-260; Bernhard Lohse. A fé cristã através dos tempos. São Leopoldo: Sinodal, 1981, p. 236238; M. A. Noll. ‘Pietismo' em Enciclopédia Histórico-Teológica da Igreja Cristã, III. São Paulo: Vida Nova, 1988.

44 Justo L. González. Historia del pensamiento Cristiano, III. Miami: Editorial Caribe, 1993. p. 307.

45 Utilizo a versão em Português: Pia desideria - um clássico do pietismo protestante. (Trad. e Apres. de Prócoro V. Filho). São Bernardo do Campo: Imprensa Metodista, 1995.

46 Bengt Hägglund, op. cit. p. 282. 
A nova orientação de Spener com respeito ao conceito de fé e à doutrina de justificação eram exemplos disso. Tal como Spener, a entendia não era mero conhecimento e confiança ${ }^{47}$; e ao mesmo tempo, tratava-se antes de uma experiência de renovação em um poder vivificante. A ênfase era, pois, na regeneração, tendo a justificação apenas como um fruto dela. Fazendo assim, Spener escapava da visão jurídica da justificação pela fé, que se tornara lugar comum no luteranismo. Nesse sentido, “a fé não era apenas a aceitação dos méritos de Cristo, mas deve levar Cristo a habitar no coração do crente" 48 . Spener propõe o renascimento de Cristo na alma, bem ao estilo dos místicos do cristianismo antigo e medieval.

Além dessas ideias gerais presentes em sua obra, Spener ofereceu em Pia desideria, algumas propostas para a renovação da igreja, que de alguma maneira são uma súmula do pietismo e sintetizam os desejos piedosos de todo o movimento pietista:

1) Que os cristãos se sintam motivados a buscar uma compreensão das escrituras mais clara e profunda [...].

2) Estudo devoto em pequenos grupos ou reuniões nos lares, pois, "[...] um dos principais propósitos da reforma foi devolver ao povo a Palavra de Deus, escondida na sacristia [...] superar a aversão que muitos têm da escritura e negligência de seu estudo, estimulando o buscar ardente e zeloso de seus ensinamentos" 49 .

3) Que o laicato redescubra o Sacerdócio Universal dos crentes, e com este propósito na mente dava aos leigos posições de responsabilidade nos grupos que fundava - "cada cristão não é só compelido a oferecer-se a si mesmo e o que possui, suas orações, ações de graça, boas obras, ofertas, etc.; como também, a estudar com seriedade a palavra do Senhor, ensiná-las a outras, com o dom que lhe foi dado [... $]^{50}$.

4) Que todos reconheçam que a natureza do cristianismo é tal que não pode limitar-se às fórmulas doutrinais, senão que é mais uma experiência de fé, e uma atitude que inclui toda a vida. As doutrinas são

47 Ibid., op cit., p. 283.

48 Ibid., loc cit.

49 Pia desideria, p. 59-60.

50 Ibid., op cit., p. 61. 
importantes, porém mais importante é a experiência e a prática da vida cristã — “[...] todos os mandamentos são resumidos no amor ( $\mathrm{Rm} 13,9)$. O povo não pode apenas ser ensinado a amar o próximo, nem só advertido sobre os perigos do amor-próprio, mas, sobretudo, exortado a praticar o amor [...] não perder a oportunidade de servir o outro com atos de amor, a sondar seus corações para saber se o motivo que os impulsiona é o verdadeiro amor, ou qualquer outro"51.

5) Que nas controvérsias reine um espírito de moderação e caridade, posto que negar tal espírito é pecado pelo menos tão grave como o erro doutrinal — “[...] tenhamos uma atitude amorosa para com os não crentes e com os heréticos. Devemos deixar-lhes claro que não temos nenhum prazer em sua incredulidade, crença ou prática errada e sua propagação [...] nem a incredulidade, nem a falsa religião podem impedir ou enfraquecer o nosso amor ao próximo"52.

6) Que as preocupações dos pastores estejam muito mais além da fria lógica e da teologia ortodoxa e inclua uma imersão profunda na literatura e prática devocional — “[...] os professos tem a obrigação de desempenhar papel importantíssimo, por seus exemplos (sem isso, dificilmente uma verdadeira reforma será alcançada), como homens que morreram para o mundo, não buscam a glória pessoal, o lucro, e o prazer, mas a glória de Deus e a salvação daqueles que o cercam [...] É necessário convencer os estudantes de que a vida santificada é tão importante quanto o senso de responsabilidade e dedicação aos estudos"53.

7) Que desta forma, o púlpito recupere seu propósito original de instruir, inspirar e alimentar os crentes, em lugar de ser utilizado para discussões técnicas que o leigo não entende - “[...] o púlpito não é lugar para a ostentação, mas para a plena e poderosa pregação da Palavra do Senhor. A prédica é um instrumento divino para a salvação das pessoas. Por isso, nele todas as coisas devem ser direcionadas para esse propósito. As pessoas comuns, das quais a

51 Ibid., op. cit., p. 62-63.

52 Ibid., op cit., p. 64.

53 Ibid., op cit., p. 68. 
comunidade é composta em sua grande maioria, não podem ser esquecidas pelo pregador preocupado em agradar os letrados que são poucos e, geralmente, não comparecem ao culto" ${ }^{54}$.

Digno de nota também, o fato de Spener indicar a literatura teológica de grandes teólogos da tradição Luterana. Nomes como: Matthäus Meyfart (1590-1642), Johann Schmidt (1594-1658), Abraham Calovius (1612-1680), Johann Gerhard (1528-1637), Nikolaus Hunnius (15851643), Christoph Scheibler (1589-1653). Ademais, recomenda um tipo de literatura devocional: Theologie Deutsche (Teologia Alemã) do século XIV, indicada por Lutero, conforme supra; os escritos de Johann Tauler ${ }^{55}$ (1300-1361). Conselho que Lutero deu a Spalatino em carta, na qual ele descreve Tauler como homem de Deus; Nachfolgung Christi - Imitação de Cristo de Tomás a Kempis, além de Santo Agostinho e Lutero que também são citados e recomendados.

Em síntese, podemos dizer que o pietismo de Spener propunha: piedade pessoal com a formação de pequenos grupos para fomentar tal piedade, ênfase na leitura pessoal das Escrituras, convicção de que o núcleo da doutrina cristã é simples com destaque para o ministério leigo. "Tudo isso se colocava dentro de um contexto epistemológico no qual a experiência pessoal era mais importante que a fé comunitária, e até mais importante que a revelação histórica" ${ }^{56}$. As energias pietistas estavam voltadas à experiência pessoal de cada indivíduo em ambiente mais informal, com certa aversão ao formato de culto litúrgico, priorizando a espontaneidade que se estimulava nos colegia pietatis na leitura simples do Evangelho.

Tal atitude abriu caminho para outras formas de pietismo, como aquele desenvolvido em Halle; nomes como Joaquim Justus Breithaupt, João Atanásio Freylinghausen, Joaquim Lange e seu líder, August Hermann Francke (1663-1727), considerado o sucessor natural de Spener e que proporcionou ao movimento uma substância teológica robusta. Buscou revitalizar tanto a teologia como a devoção, além da prática missionária. Talvez

54 Ibid., op cit., p. 76.

55 Com destaque para os seus Instituciones - Temas de oración. Salamanca: Sígueme, 1990.

56 Justo González, op cit., p. 308. 
a diferença marcante em relação a Spener seja quanto ao arrependimento, pois Francke entendia que o homem é levado ao ponto em que decide romper com o mundo e iniciar nova vida. É então que o dom da fé lhe é outorgado, e é por meio dessa fé que recebe o perdão dos pecados.

Esses pietistas entenderam ser a grande comissão dada por Cristo, um compromisso de todos os cristãos, e que, portanto, todos eram responsáveis da conversão dos não crentes. Com tal desafio, a Universidade de Halle veio a ser um centro para o treinamento de missionários. No entanto, a experiência seguiu sendo a alma do movimento e, por isso mesmo, a exposição teológica pietista passou a tratar principalmente de fatos religiosos empíricos, uma vez que pressupunha que o conhecimento teológico não podia ser adquirido sem a experiência da regeneração (novo nascimento). Dessa maneira, o pietismo inaugura uma nova forma de fazer teologia, oferece à cristandade uma nova eclesiologia.

Outra vertente pietista foi a ala radical em estreita relação com os entusiastas da época. Nesse segmento houve a combinação de religiosidade fanática e mística com a crítica racionalista da doutrina ortodoxa da igreja. Nesse particular surge o nome e a influência de Jacob Boehme (1575-1624) ${ }^{57}$, considerado o principal líder desta tendência no pietismo e que entendia haver na Escritura um sentido oculto, semelhante ao neoplatonismo de Orígenes, que poderia ser acessado apenas por uma iluminação, compreendido como o processo do novo nascimento em Deus. Com isso, o novo critério de verdade que pode dar segurança é precisamente esta iluminação pelo Espírito de Deus. Boehme rejeita e critica a doutrina da justificação em seu sentido forense.

Além disso, deves gravar em tua mente que, pelo mérito de Jesus Cristo, alcançarás a graça prometida e participarás de seu transbordante amor. Em verdade, Cristo já vive em ti, iluminando tua vontade e inflamando-a com a chama de seu amor. Ele te libertará de tuas criaturas e te dará a vitória sobre o diabo ${ }^{58}$.

57 Em Português dispomos de apenas quatro de suas obras: BOEHME, J. A aurora nascente. São Paulo: Paulus, 1998; BOEHME, J. A sabedoria divina: o caminho da iluminação. São Paulo: Attar Editorial, 1998; BOEHME, J. "Seis pontos teosóficos". In: Ciência, sentido e evolução. São Paulo: Attar Editorial, 1996; BOEHME, J. A revelação do grande mistério divino. São Paulo: Editora Polar, 1997.

58 BOEHME, J. A sabedoria divina. São Paulo: Attar Editorial, 1998. p. 140.

Rev. Pistis Prax., Teol. Pastor., Curitiba, v. 10, n. 3, 657-681, set./dez. 2018 
A ele se juntaram pensadores, teólogos como, Johann Pedersen (1649-1727), Gottfried Arnold (1666-1714), J. Conrad Dippel (16721734), Gerhard Tersteegen (1697-1769) e vários outros.

Por fim, temos a Comunidade de Herrnhut e o Conde Nicolaus Ludwig von Zinzendorf (1700-1760). Inicialmente, Zinzendorf fora diretamente influenciado pelo pietismo de Halle, em relação direta com Francke, de quem fora aluno, época na qual, segundo J. Delumeau, teve contato com uma literatura católica de vertente mística nas "obras de François Fénelon e de Madame Guyon"59. Zinzendorf travou contato com os irmãos moravianos ${ }^{60}$ e, desde 1722 , cedeu-lhes parte de sua propriedade na Saxônia. Cinco anos depois estava fundada a Comunidade Herrnhut. V. Steuernagel registra, "o dia 13 de agosto de 1727. Naquele dia, durante um culto com ceia, o Espirito Santo, como diz Zinzendorf, "desceu sobre a congregação" e o resultado foi uma profunda renovação e comprometimento espiritual" 61 . Herrnhut tinha em sua constituição elementos tanto da teologia, como da liturgia Luterana, somadas com a renovação do pietismo de Halle em sua ênfase nas missões e, de fato, enviando missionários a vários países. Também, principalmente o influxo da piedade católica dissidente dos moravianos, movimento que experimentou uma história de perseguição religiosa.

De fato, toda a teologia de Zinzendorf descansa sobre um fundamento: a realidade da comunhão e intimidade com Cristo, a cláusula paulina em Cristo tão cara a Lutero, estava em Herrnhut como "pedra angular". Tal comunhão depende da contemplação do Cristo crucificado. S. Neil, descreve que "Herrnhut, desenvolveu a sua forma peculiar

59 DELUMEAU, J. Nascimento e afirmação da reforma. São Paulo: Pioneira, 1989. p. 242.

60 Tratava-se de um remanescente do movimento Unidade dos irmãos - Unitas fratem, originários da região da Boêmia e que foram perseguidos pelos Habsburgos. Eram católicos, mas com uma prática devocional evangélica. Seu Líder era o carpinteiro Christian David. Em seus inícios contou nas suas fileiras o educador J. Comenius, pioneiro na educação protestante com sua Didática Magna. Sobre os moravianos e a Comunidade Herrnhut em Português, ver: Valdir Steuernagel. Obediência missionária e prática histórica: Em busca de modelos. São Paulo: ABU 1993, p. 92 a 120. Todo o cap. 4 desta obra está dedicado aos Irmãos Morávios. Trata-se ainda, segundo me consta, do texto mais completo sobre eles em nossa Língua, com excelente aparato crítico. Ver também: Stephen Neil. História das missões. São Paulo: Vida Nova, 1989. p. 242-244.

61 Valdir Steuernagel, op. cit., p. 101. 
de pietismo, com profunda devoção pelo Redentor crucificado [...]"62. Portanto, sua devoção e espiritualidade é mística de Cristo. Em Cristo e nos seus sofrimentos, reside todo o sentido verdadeiro da teologia. Com isso, todo conhecimento de Deus vem por meio da revelação de Cristo, por via contemplativa e mística, é sem dúvida uma releitura com muito mais abertura e liberdade do solus Christus da Reforma.

\section{Considerações finais}

O movimento de reforma desenvolvido no segmento luterano, estando vinculado aos acontecimentos históricos da política, da economia, da religião e da cultura em geral, não poderia deixar de refletir tais condições na versão do cristianismo que apresentou. De fato, tais fatores agiram como forças condicionantes na veiculação que se pretendia dar ao Evangelho em sua interpretação e aplicação. Ainda que revelasse em suas proposições notas de originalidade consoantes aos novos tempos que rapidamente se insinuavam diante do "outono da Idade Média", em seu fenômeno de continuidade, revelou igualmente uma forte ligação com categorias espirituais do passado medieval e antigo. Concomitantemente, manteve a tensão existencial tão marcante da personalidade e carisma de seu fundador. Assim, o moderno e o antigo se revezavam e se mesclavam à medida que novas lideranças iam surgindo. O simul iustus... de Lutero sobre a antropologia cristã, acabou valendo para o luteranismo como um todo. Conseguiu tratar com ambiguidades e contradições de forma simultânea. Fazendo assim, enriquecer notavelmente a cultura cristã no Ocidente, dando importante contribuição à espiritualidade protestante. Se a princípio pendeu para um biblicismo exacerbado, assumindo posturas quase fideístas no âmbito da ortodoxia, a recuperação do Lutero histórico e de sua espiritualidade no contexto pietista foi uma renovação com repercussões na missiologia e no ecumenismo, mas esta é uma outra história!

62 Stephen Neil, op cit., p. 242. 


\section{Referências}

BAYER, O. A teologia de Martim Lutero. São Leopoldo: Sinodal, 2007.

BECK, N. Comentário ao artigo 6 da Confissão da esperança: Exposição histórica e doutrinária da Confissão de Augsburgo. Porto Alegre: Concórdia, 1980.

BOEHME, J. Seis pontos teosóficos. In: Ciência, sentido e evolução. São Paulo: Attar Editorial, 1996.

BOEHME, J. A sabedoria divina: o caminho da iluminação. São Paulo: Attar Editorial, 1998.

BOEHME, J. A revelação do grande mistério divino. São Paulo: Editora Polar, 1997.

BONNARD, P. Justo. In: von ALLMEN, J.-J. (dir.). Vocabulário Bíblico. São Paulo: ASTE, 2001.

DELUMEAU, J. Nascimento e afirmação da reforma. São Paulo: Pioneira, 1989.

DUNN, J. A teologia do apóstolo Paulo. São Paulo: Paulus, 2003.

EBELING, G. O pensamento de Lutero. São Leopoldo: Sinodal, 1988.

HÄGGLUND, B. História da Teologia. Porto Alegre: Concórdia, 1981.

GONZÁLEZ, J. L. Historia del pensamiento Cristiano, III. Miami: Editorial Caribe, 1993.

HEIMANN, L. Comentário ao artigo 12 da Confissão da esperança Exposição histórica e doutrinária da Confissão de Augsburgo. Porto Alegre: Concórdia, 1980.

KÄSEMANN, E. Perspectivas paulinas. São Paulo: Teológica, 2003.

KAUFMANN, T. Martín Lutero: Vida, mundo, palabra. Madrid: Trotta, 2017.

LOEWENICH, W. von. A teologia da cruz de Lutero. São Leopoldo: Sinodal, 1988.

LOHSE, B. A fé cristã através dos tempos. São Leopoldo: Sinodal, 1981.

LUTERO, M. Os Catecismos. Porto Alegre/São Leopoldo: Concórdia/Sinodal, 1983.

LUTERO, M. Tratado sobre a liberdade cristã. In: Obras selecionadas, v. 2. São Leopoldo/Porto Alegre: Sinodal/Concórdia, 1989. 
LUTERO, M. Debate Acerca da Justificação (1535). In: Obras selecionadas, v. 3. São Leopoldo/Porto Alegre: Sinodal/Concórdia, 1992.

LUTERO, M. Prefácio à epistola de S. Paulo aos Romanos (1546). In: Obras selecionadas, v. 8. São Leopoldo/ Porto Alegre: Sinodal/Concórdia, 2003.

LUTERO, M. Epístola do bem-aventurado Apóstolo Paulo aos Romanos. In: Obras selecionadas, v. 8. São Leopoldo/Porto Alegre: Sinodal/Concórdia, 2003.

MAROTO, D. de P. História de la espiritualidade cristiana. Madrid: EDE, 1990.

MONTES, A. G. Reforma luterana y tradicón católica. Salamanca: UPS, 1987.

MONTES, A. G. Justificados em Jesucristo: La justificación en el diálogo ecuménico actual. Salamanca: UPS, 1989.

MUELLER, J. T.; REHFELDT, M. L. As confissões luteranas, história e atualidade. Porto Alegre: Concórdia, 1980.

NEIL, S. História das missões. São Paulo: Vida Nova, 1989.

NOLL, M. A. 'Pietismo' em Enciclopédia Histórico-Teológica da Igreja Cristã, III. São Paulo: Vida Nova, 1988.

OBERMAN, H. Lutero: Un hombre entre Dios y el diablo. Madrid: Alianza Editorial, 1992.

PESCH, O. H. La gracia como justificación y santificación del hombre. In: Misterium Salutis: Manual de teologia como historia de la salvación IV/2 - La Iglesia. Madrid: Cristiandad, 1984.

SCHWEITZER, A. The mysticism of Paul the apostle. Baltimore/London: The John Hopkins University Press, 1998.

SPENER, P. J. Pia desideria: um clássico do pietismo protestante. São Bernardo do Campo: Imprensa Metodista, 1995.

STEUERNAGEL, V. Obediência missionária e prática histórica: Em busca de modelos. São Paulo: ABU, 1993.

TAULER, J. Instituciones: Temas de oracíon. Salamanca: Sígueme, 1990. 
THIEMANN, R. F. A teologia da cruz de Lutero: Subsídio para uma teologia das religiões. In: HELMER, C. (Ed.). Lutero: um teólogo para tempos modernos. São Leopoldo: Sinodal, 2013.

THOMPSON, C. El poeta y el místico: Un estudio sobre el Cántico espiritual de San Juan de la Cruz. Madrid: Torre de la Botica Swan, 1963.

TILLICH, P. História do pensamento cristão. São Paulo: ASTE, s/d.

TILLICH, P. Teologia sistemática. São Leopoldo/São Paulo: Sinodal/Paulinas, 1987.

VAJTA, V. Justificação. In: CONGAR, Y. (dir.). Vocabulario Ecuménico. Barcelona: HERDER, 1972.

VINAY, V. Protestantes e Anglicanos. In: GOFFI, T.; SECONDIN, B. (Orgs.). Problemas e perspectivas de espiritualidade. São Paulo: Loyola, 1992.

Recebido: 22/06/2018

Received: 06/22/2018

Aprovado: 16/10/2018 Approved: 10/16/2018 